\title{
Teaching Supply Chain Operations Planning Using Actual Industry Data Across Multiple Organizations
}

Dr. Michael S. Pepe, Siena College, USA

\begin{abstract}
The purpose of this case study is to provide a pedagogical teaching tool from a business-oriented viewpoint for an undergraduate supply chain management class. Students are provided with challenging questions and problems to solve which enriches their analytical skills in assessing product assortments, developing effective forecasting techniques and collaborative decision making skills with operation managers and supply chain partners. This case examines supply chain management as a collaborative function intertwined with other organizational tasks and provides future supply chain managers lessons on interactions and integration of multiple business units using the latest business practice examples in supply chain management. The case was developed through interviews with eight supply chain professionals across six organizations and uses actual POS data from a retailer.
\end{abstract}

Key words: Supply Chain Pedagogy; Operations Planning; Product Assortment

\section{INTRODUCTION}

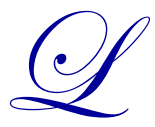

ogistics has traditionally upheld a close relationship between academics and business professionals with the evolution of logistics education having implications for pedagogy, curriculum, and industry. Practitioner concerns recently have focused on how logistics job growth has outpaced the number of graduates with new graduates too frequently arriving at the workplace less than adequately prepared for careers as logistics managers (Gravier \& Farris, 2008).

At $\$ 1.3$ trillion and 9.9 percent of gross domestic product, logistics constitutes a significant portion of the national economy and justifies the implementation of more effective educational methods. Evidence suggests that the focus of logistics educational programs on practical relevance has already proven its effectiveness (Wilson, 2007). Regarding practical relevance, early partnerships between industry and education helped guide educators to evolve logistics education to address practitioner needs. Increased interest in logistics education and changing environmental factors indicate the need for continued collaboration to further logistics education (Gravier \& Farris, 2008).

This case was developed with the objective of enhancing the instruction of supply chain integrated operations planning through the presentation of actual data obtained from a retailer. Interviews were conducted with eight industry supply chain professionals from six different organizations with diverse areas of expertise (two retailing category managers, two warehouse managers, two manufacturer agents, and two information technology specialists) to review the case and add input ensuring an application case for students that is as realistic as possible.

After analyzing the case, students will benefit from exposure to actual POS (point of sale) data and decisions made by supply chain managers throughout the supply chain in various positions. The case incorporates aspects of upstream and downstream supply chain collaborative decision making from a manufacturing through end consumer perspective. 
This case contributes to several objectives for a supply chain management course:

1) Exposing students to "real world" supply chain management problems and the difficulty associated with those problems. This case focuses primarily on the issues of assortment planning and supply chain coordination.

2) Building student skills in thoughtfully and critically evaluating essential functions of logistics management and supply chain.

3) Providing students with an understanding of the methods and tools used by today's logistics managers. An applied, problem-solving approach will be used as the learning focus.

4) Implementing supply chain marketing strategies in an effective and profitable manner.

\section{CASE BACKGROUND AND PERFORMANCE STATISTICS}

Stephen Singer sat in his office reviewing his end of year performance and contemplating plans for the upcoming year. As category manager for a supermarket retailer, Stephen was reviewing the results of the olive oil category that produced less than stellar results in 2009. He knew the upcoming year would present numerous challenges with increased competitive pressures and expectations of senior management to meet established objectives. A vital component to achieving objectives in 2010 would be logistical planning and coordination of inventory and warehousing within his firm and between supply chain partners.

As a supply chain management professional, Stephen knew that additional Sales and Operations Planning (S\&OP) along with Collaborative Planning, Forecasting and Replenishment (CPFR) initiatives needed to be implemented to improve performance in 2010. An integrated S\&OP process would collaboratively establish coordinated plans across organizational departments to meet customer requirements within resource constraints. The CPFR process would involve joint business planning with supply chain partners to share information for demand creation and fulfillment activities.

The key marketing metrics Stephen was responsible for in the olive oil category in 2009 were market share, sales volume, unit volume and gross profit dollars and results in all four areas were substandard compared to established goals. Sales volume for the year increased $.79 \%$ compared to a $5 \%$ budgeted increase; unit volume decreased $14.97 \%$ versus a goal of a $5 \%$ increase; margin dollars increased $4.06 \%$ compared to a budgeted goal of $5 \%$; market share declined from $24.1 \%$ to $23.9 \%$ compared to goal of $24.5 \%$ share. Table 1 contains actual results compared to objectives.

Table 1: 2009 Results vs. Objectives

\begin{tabular}{|l|c|c|c|c|}
\hline OLIVE OIL CATEGORY & Year End 2009 & Year End 2008 & Variance-\% Change & Objective For Year \\
\hline Sales & $\$ 7,642,086$ & $\$ 7,582,170$ & $.79 \%$ & $5 \%$ increase \\
\hline Units & 929,057 & $1,092,639$ & $-14.97 \%$ & $5 \%$ increase \\
\hline Gross Margin \$ & $\$ 2,651,557$ & $\$ 2,548,074$ & $4.06 \%$ & $5 \%$ increase \\
\hline Market Share & $23.9 \%$ & $24.1 \%$ & & $24.5 \%$ share \\
\hline
\end{tabular}

Stephen knew that in order to meet the targeted objectives in 2010, which are identical to the 2009 goals, he needed to focus on two key S\&OP and CPFR areas:

1) Product assortment and $S \& O P$ decisions involving which sku's (stock keeping units or items) to offer to consumers. This problem was compounded by the warehouse supervisor mandating that the product assortment in the olive oil category be reduced from 61 to 50 items due to warehouse space constraints to allow room for new natural and organic products, a growing segment of the business that is desired by consumers but currently being underserved by the retailer.

2) Improved CPFR and POS data sharing with suppliers to better forecast promotions resulting in reduced out of stocks and excessive inventory. Achievement of more effective forecasting will result in enhanced category sales, gross profits, and satisfaction. 


\section{PART 1- PRODUCT ASSORTMENT AND S\&OP DECISIONS}

In order to achieve his objectives, Steve was evaluating the product assortment mix in the olive oil category. Effective Sales and Operations Planning (S\&OP) was necessary as warehouse managers were constrained by warehouse capacity and needed to reduce the number of sku's stocked in certain categories to make room for the growing natural and organic segment that consumer's desire.

After a private meeting with Wayne Hull, the warehouse supervisor, Stephen was told that the number of olive oil sku's offered to consumers would have to be reduced from the current level of 61 to 50 in the upcoming year. Steve conducted a market analysis of competitors to assess their product assortment by brand which would factor into his decisions (Table 2).

Table 2: Number Of Olive Oil Sku's By Brand For Competitors

\begin{tabular}{|l|c|c|c|c|c|}
\hline \multicolumn{1}{|c|}{ Brands } & Steve's Company & Competitor A & Competitor B & Competitor C & Competitor D \\
\hline Private Label & 23 & 14 & 7 & 12 & 15 \\
\hline Berio & 10 & 6 & 8 & 9 & 11 \\
\hline Bertolli & 6 & 2 & 7 & 3 & 6 \\
\hline Botticelli & 8 & 0 & 0 & 0 & 0 \\
\hline Carapelli & 9 & 5 & 4 & 9 & 0 \\
\hline Colavita & 5 & 1 & 0 & 5 & 4 \\
\hline Total \# sku's & $\mathbf{6 1}$ & $\mathbf{2 8}$ & $\mathbf{2 6}$ & $\mathbf{3 8}$ & $\mathbf{3 6}$ \\
\hline
\end{tabular}

The market analysis illustrated that Stephen's product assortment far exceeded all competitors and that the Botticelli brand was offered exclusively by his organization in the market. In addition to a competitor analysis, Stephen analyzed the Point of Sale (POS) internal database of his company which contained information on the performance of each sku in the past year. This information would form the basis of his assortment decisions and is contained in Table 1A in the Appendix. Total sales and units for each of the 61 sku's, separated by national brand and private label, in 2009 is compared to 2008 results with the percentage change of each provided.

One addition source of data that Stephen needed to evaluate his assortment decision was brand share, both in sales and units, at his organization and in comparison to the rest of the market (ROM). Table 3 provides this information with key highlights as follows:

- $\quad$ Private label represents $26.63 \%$ of sales at his organization compared to $14.62 \%$ ROM

- $\quad$ Berio represents $28.58 \%$ of sales at his organization compared to $36.75 \% \mathrm{ROM}$

- $\quad$ Private label represents $33.67 \%$ of units at his organization compared to $19.50 \%$ ROM

- $\quad$ Berio represents $24.69 \%$ of units at his organization compared to $34.19 \% \mathrm{ROM}$

Table 3: Olive Oil Brand Share versus ROM (Rest Of Market) - Top 4 Brands

\begin{tabular}{|l|c|c|c|c|c|}
\hline & Private Label & Berio & Bertolli & Carapelli & All Others \\
\hline $\begin{array}{l}\text { \% of total sales for } \\
\text { Steve }\end{array}$ & $26.63 \%$ & $28.58 \%$ & $13.00 \%$ & $11.90 \%$ & $19.80 \%$ \\
\hline $\begin{array}{l}\text { \% of total units for } \\
\text { Steve }\end{array}$ & $33.67 \%$ & $24.69 \%$ & $15.07 \%$ & $10.42 \%$ & $16.15 \%$ \\
\hline \% of total sales at ROM & $14.62 \%$ & $36.75 \%$ & $6.66 \%$ & $9.94 \%$ & $32.03 \%$ \\
\hline \% of total units at ROM & $19.50 \%$ & $34.19 \%$ & $5.56 \%$ & $10.51 \%$ & $30.23 \%$ \\
\hline
\end{tabular}




\section{Part 1 Discussion Questions and Tasks:}

1) Describe the S\&OP process. What are the major trade-offs that must be considered in this situation?

2) Discuss how a minor change in demand at the retail level can significantly impact supply chain variation at distributors and manufacturers.

3) Analyze the excel spreadsheet in Table 1A of the Appendix. What key insights do you find?

4) Only 50 items can be offered during 2010. Select, and provide rationale, for 11 items that should be discontinued.

5) Calculate margin $\$$ and all cells on the excel spreadsheet in Table 1A of the Appendix. How do these calculations factor into your assortment recommendation?

\section{PART 2- IMPROVED CPFR AND POS DATA SHARING}

Stephen identified working more closely with suppliers as a key initiative for the upcoming year. He knew that the initial step in the CPFR process was joint business planning where customers and suppliers share, discuss and coordinate their individual strategies to create a joint plan. This joint plan would offer a common and consistent vision of what is expected to be sold, how it will be merchandised and promoted, and during what time period.

Stephen setup a planning session with members from SALVO North America Corporation, importers of Berio olive oil, to formulate plans for the first three months of 2010. POS data from the first quarter of 2009 was obtained to initiate the planning session which shows unit scan movement for each sku and promotional weeks with sale price and is contained in Table 2A - Berio CPFR in the Appendix.

Key comments regarding this data are as follows:

- $\quad$ A promotion for $101 \mathrm{oz}$ was run the week of January 8 at $\$ 24.99$ in 2009 and will be repeated in 2010 at the same price and same week.

- A two week promotion was run the week of January 22 and 29 in 2009 at BOGO (buy 1, get 1) and will be repeated in 2010with the dates changing to February 19 and 26.

- $\quad$ A 13 week TPR (temporary price reduction) at $\$ 5.99$ was run on $17 \mathrm{oz}$ in 2009 and will be repeated in 2010

\section{Part 2 Discussion Questions and Tasks:}

1) CPFR has been shown to improve forecasting accuracy for manufacturers. What are the major challenges associated with using CPFR? Given its demonstrated benefits, discuss when CPFR should or should not be used by firms.

2) How does the CPFR process improve (a) logistics planning (b) production planning?

3) Describe how the CPFR process should assist Stephen in meeting sales goals by reducing out of stocks.

4) Describe how this process should assist Stephen in meeting gross profit goals by minimizing markdowns from excessive inventory after promotional periods.

5) Given that unit volume is budgeted to increase by $5 \%$ in 2010 , fill in a projected forecast for each sku by week on the excel spreadsheet in Table 2A (see Appendix).

\section{AUTHOR INFORMATION}

\section{Michael S. Pepe}

Michael S. Pepe, DBA, is an assistant professor of marketing in the School of Business. Dr. Pepe's teaching interests pertain to marketing strategy, marketing pedagogy, marketing metrics, and international marketing. An integral component of Dr. Pepe's teaching methodology is application of all concepts presented to students that were developed during his 19 years of professional marketing experience. Michael has published his research in areas involving branding, organizational commitment, point of sale data analysis, and customer lifetime value. He has published in the Journal of Product and Brand Management, Journal of Marketing Management, Journal of Business Case Studies and the Journal of Business and Economics Research. Michael has been a member of the American 
Marketing Association for numerous years and is currently the co-advisor for the Siena student chapter. Please contact Dr. Pepe at www.siena.edu for the complete data set to be used in this case.

\section{REFERENCES}

1. Bowersox, D., Closs, D., Cooper, M., \& Bowersox J. (2013). Supply Chain Logistics Management. $4^{\text {th }}$ edition. New York, New York: McGraw-Hill.

2. Gravier, M., \& Farris, M. (2008). An analysis of logistics pedagogical literature: Past and future trends in curriculum, content, and pedagogy," International Journal of Logistics Management, 19 (2), 233 - 253.

3. Wilson, R. (2007). 18 $8^{\text {th }}$ Annual State of Logistics Report. Council of Supply Chain Management Professionals. Washington, DC. 


\section{APPENDIX}

\begin{tabular}{|c|c|c|c|c|c|c|c|c|c|c|c|c|}
\hline \multicolumn{13}{|c|}{ Table 1A: Olive Oil Performance by SKU } \\
\hline & & & & & Year End & Data & Year End & Data & & & & \\
\hline & & & & & 2008 & 2008 & 2009 & 2009 & 2009 & 2009 & 2009 & 2009 \\
\hline Upc & Item Description & Pack & Size & RETAIL & Total Sales & Units & Total Sales & Units & $\%$ \$ CHG. & $\begin{array}{c}\text { \% UNIT } \\
\text { CHG. }\end{array}$ & Margin \% & Margin \$ \\
\hline 4173600011 & BERIO OLIVE OIL & 4 & $101 \mathrm{Z}$ & 27.99 & $\$ 282,587$ & 10,096 & $\$ 354,913$ & 12,680 & $25.72 \%$ & $25.59 \%$ & & \\
\hline 4173601011 & BERIO X VIRGIN OIL & 4 & $101 \mathrm{Z}$ & 27.99 & $\$ 249,795$ & 11,618 & $\$ 341,577$ & 16,295 & $36.74 \%$ & $40.26 \%$ & & \\
\hline 4173600028 & BERIO PURE OLIVE OIL & 6 & $51 \mathrm{OZ}$ & 14.99 & $\$ 148,841$ & 10,562 & $\$ 193,221$ & 14,164 & $29.82 \%$ & $34.10 \%$ & & \\
\hline 4173601028 & BERIO XVIRG OLIVE OIL & 6 & $51 \mathrm{OZ}$ & 14.99 & $\$ 156,466$ & 10,438 & $\$ 268,876$ & 17,937 & $58.85 \%$ & $71.84 \%$ & & \\
\hline 4173600160 & BERIO OLIVE OIL & 12 & $25.5 Z$ & 8.59 & $\$ 238,078$ & 32,145 & $\$ 256,063$ & 33,368 & $7.55 \%$ & $3.80 \%$ & & \\
\hline 4173601013 & BERIO XVG OLIVE OIL & 12 & 25.50 & 8.59 & $\$ 347,474$ & 40,451 & $\$ 463,954$ & 54,011 & $31.21 \%$ & $33.52 \%$ & & \\
\hline 4173603013 & BERIO X LT OLIVE OIL & 12 & $25.5 Z$ & 8.59 & $\$ 130,823$ & 17,670 & $\$ 153,355$ & 20,416 & $17.22 \%$ & $15.54 \%$ & & \\
\hline 4173600180 & BERIO OLIVE OIL & 12 & $17 \mathrm{OZ}$ & 6.49 & $\$ 269,372$ & 57,493 & $\$ 186,651$ & 31,448 & $-30.71 \%$ & $-45.30 \%$ & & \\
\hline 4173601014 & BERIO EXTRA VIRGIN & 12 & $17 \mathrm{OZ}$ & 6.49 & $\$ 340,907$ & 52,528 & $\$ 319,438$ & 49,220 & $3.74 \%$ & $-6.30 \%$ & & \\
\hline \multirow[t]{2}{*}{4173603014} & BERIO LIGHT OLIVE OIL & 12 & $17 \mathrm{OZ}$ & 6.49 & $\$ 200,911$ & 44,457 & $\$ 148,374$ & 25,928 & $-26.15 \%$ & $-41.68 \%$ & & \\
\hline & & & & & $\$ 2,365,253$ & $\$ 287,458$ & $\$ 2,686,421$ & $\$ 275,467$ & $13.58 \%$ & $-4.17 \%$ & $36.64 \%$ & \\
\hline
\end{tabular}

(Please contact Dr. Michael Pepe for the entire spreadsheet containing information for all 61 sku's) 


\begin{tabular}{|c|c|c|c|c|c|c|c|c|c|c|c|c|c|c|c|c|c|c|}
\hline \multicolumn{19}{|c|}{ Table 2A-Berio CPFR } \\
\hline \multirow[b]{2}{*}{ Upc } & \multirow{2}{*}{$\begin{array}{l}\text { AD } \\
\text { Item Description }\end{array}$} & \multirow[b]{2}{*}{$\begin{array}{c}\text { Regular } \\
\text { Retail }\end{array}$} & \multirow[b]{2}{*}{ Pack } & \multirow[b]{2}{*}{ Size } & \multicolumn{13}{|c|}{ 2009 Actual results-week of: } & \multirow[b]{2}{*}{ TOTAL } \\
\hline & & & & & 1-Jan & 8-Jan & 15-Jan & 22-Jan & 29-Jan & 5-Feb & 12-Feb & 19-Feb & 26-Feb & 5-Mar & 12-Mar & 19-Mar & 26-Mar & \\
\hline 4173600011 & $\begin{array}{l}\text { BERIO OLIVE } \\
\text { OIL }\end{array}$ & $\$ 27.99$ & 4 & $101 \mathrm{Z}$ & 244 & 600 & 100 & 210 & 230 & 210 & 320 & 198 & 225 & 260 & 201 & 192 & 180 & 3170 \\
\hline 4173601011 & $\begin{array}{l}\text { BERIO X VIRGIN } \\
\text { OLIVE OIL }\end{array}$ & $\$ 27.99$ & 4 & $101 \mathrm{Z}$ & 313 & 760 & 150 & 280 & 300 & 344 & 415 & 204 & 280 & 360 & 220 & 230 & 245 & 4101 \\
\hline 4173600028 & $\begin{array}{l}\text { BERIO PURE } \\
\text { OLIVE OIL }\end{array}$ & $\$ 14.99$ & 6 & $51 \mathrm{OZ}$ & 272 & 302 & 194 & 255 & 290 & 241 & 274 & 300 & 244 & 238 & 305 & 276 & 350 & 3541 \\
\hline 4173601028 & $\begin{array}{l}\text { BERIO XVIRG } \\
\text { OLIVE OIL }\end{array}$ & $\$ 14.99$ & 6 & $51 \mathrm{OZ}$ & 345 & 375 & 251 & 328 & 375 & 326 & 391 & 402 & 331 & 280 & 380 & 350 & 350 & 4484 \\
\hline 4173600160 & $\begin{array}{l}\text { BERIO OLIVE } \\
\text { OIL }\end{array}$ & $\$ 8.59$ & 12 & $25.5 \mathrm{Z}$ & 499 & 602 & 598 & 2987 & 2621 & 430 & 459 & 503 & 629 & 599 & 558 & 600 & 542 & 11627 \\
\hline 4173601013 & $\begin{array}{l}\text { BERIO XVG } \\
\text { OLIVE OIL }\end{array}$ & $\$ 8.59$ & 12 & $25.5 \mathrm{O}$ & 950 & 989 & 941 & 4221 & 3258 & 660 & 689 & 756 & 989 & 947 & 999 & 967 & 916 & 17282 \\
\hline 4173603013 & $\begin{array}{l}\text { BERIO X LT } \\
\text { OLIVE OIL }\end{array}$ & $\$ 8.59$ & 12 & $25.5 Z$ & 299 & 305 & 261 & 2527 & 2121 & 231 & 258 & 302 & 310 & 296 & 360 & 320 & 285 & 7875 \\
\hline 4173600180 & $\begin{array}{l}\text { BERIO OLIVE } \\
\text { OIL }\end{array}$ & $\$ 6.49$ & 12 & $17 \mathrm{OZ}$ & 605 & 710 & 620 & 517 & 548 & 599 & 620 & 641 & 582 & 630 & 587 & 599 & 604 & 7862 \\
\hline 4173601014 & $\begin{array}{l}\text { BERIO X VIRGIN } \\
\text { OLIVE OIL }\end{array}$ & $\$ 6.49$ & 12 & $17 \mathrm{OZ}$ & 947 & 1058 & 980 & 836 & 880 & 930 & 985 & 1002 & 923 & 996 & 926 & 910 & 932 & 12305 \\
\hline 4173603014 & $\begin{array}{l}\text { BERIO LIGHT } \\
\text { OLIVE OIL }\end{array}$ & $\$ 6.49$ & 12 & $17 \mathrm{OZ}$ & 499 & 600 & 520 & 374 & 458 & 468 & 540 & 610 & 476 & 600 & 410 & 451 & 476 & 6482 \\
\hline
\end{tabular}

Sample of excel spreadsheet-entire spreadsheet contains information to project 2010 unit movement 
